\title{
Reading in Harmony: An Introduction
}

The craft of textual exegesis shares much in common with the interpretation of music. Both projects require a set of skills of attunement that must be cultivated over many years: careful listening, perceptiveness to subtlety and the sublime, and the open-heartedness to be moved and transformed by the object of one's interpretive attention. This art also requires a willingness to revisit the same compositions many times over, always plumbing the well in the search for deeper resonances or layers of meaning. Exegesis of texts as well as that of music requires attention to the silence, whether to the white spaces on the page or the pauses between the notes. One must also have an ear to what remains unspoken and unexpressed, glancing toward the font of inspiration that generated this artistic work and indeed continues to flow through it.

The meeting grounds of interpretation generate new ideas and vistas of experience, heights that cannot be attained if one's close reading is driven forward by a hermeneutic of immediate suspicion. A critical eye is an invaluable asset, but the interpreter whose project is driven by weary cynicism will miss many of the riches that are hidden in plain sight. Melodies and words are gateways to the infinite expanse of the human spirit and creativity. But sensitive and thoughtful exegesis is itself a kind of song, a duet between text and reader in which both are transformed through the encounter by the synergy of the voices.

A disciple of the Ba'al Shem Tov offered the following image regarding the power of music to stir the heavens: the upper and lower worlds, he said, are like two musical instruments tuned to the same key. ${ }^{1}$ When the string

1 Toledot Yaakov Yosef (Koretz: 1781), tzav. 
of one is plucked, its resonant sound will cause the strings of the second to reverberate with music as well. Imagining the interpreter as one instrument and the text as the other, this metaphor points to the encounter with a text as carefully strumming the strings of tradition. The exegete cannot be too far removed, for one must sense the vibrations of the text and be ready to follow its lead. Only through finding the correct note may the threads of the text bring music to the heartstrings. Textual exegesis, we might say, is deeply repercussive.

The Jewish tradition offers many terms for different modalities of textual interpretation and explanation, the result of several millennia of unflagging commitment to unpacking sacred texts. The most common and best known of these terms is "midrash," a noun formed from the Hebrew root $\mathrm{DaRaSH}$ - to seek out or inquire. ${ }^{2}$ The project of midrash, which encompasses legal exegesis, theological interpretation, and very much more, may correctly be described as the heart of rabbinic Judaism. In dialogue with other interpretative traditions, medieval Jewish scholars developed a multi-layered approach that is commonly called $P a R D e S$, a fourfold exegetical structure of meaning: peshat ("plain-sense"), remez ("associative"), derash ("allusory"), and sod ("mysterious," "esoteric"). These terms have been deployed across the centuries in different ways by various authors, many of whom have prided one layer over all the others. Jewish thinking on these terms is rich, though largely unsystematic and idiosyncratic.

Such an approach to texts as holding a nearly infinite array of meanings, grounded in rabbinic conceptions in Scripture and expanded as the generations went on, is crucial for understanding the literature of Kabbalah and Hasidism. The Jewish mystical literature sees the Torah as a verdant textual garden overflowing with secrets, for each of its letters holds an untold number of new interpretations. Because Scripture is a linguistic embodiment of the invisible and ineffable Divine, medieval mystics depict the text of the Torah as the central medium through which the chasm between the human and divine realms may be bridged. Such sources describe the movement of interpretation as a revelatory experience.

2 See Nehemia Polen, "Derashah as Performative Exegesis in Tosefta and Mishnah," Midrash and the Exegetical Mind, ed. Lieve Teugels, Rivka Ulmer (Piscataway, NJ: Gorgias Press, 2010), 123-153; idem, "The Spirit Among the Sages: Seder Olam, the End of Prophecy and Sagely Illumination," It's Better to Hear the Rebuke of the Wise than the Songs of Fools (Qoh 7:5), ed. David Nelson, Rivka Ulmer (Piscataway, NJ: Gorgias Press, 2015), 83-94. 
Of course, the ideals of creativity and tradition may strain against one another in many Jewish works. This often tense but fructifying relationship, which appears in unique forms in all periods, is most pronounced in the self-reflective works of modern exegesis. Rabbi Abraham Isaac Kook, for example, distinguishes between two different modalities of exegesis that complement and sustain each other. The first of these is perush, defined as "expansion" or "spreading forth" (as in Isa 25:11) in the quest to broaden our pool of understanding through the "intellectual encounter (pegishah) with the knowledge that we have already, to clarify and to expand it."3 The unfolding project of interpretation stretches and renews the tradition by allowing no stone to remain unturned. But, says Rabbi Kook, there is a second type of exegesis, called be'ur, which relates to the Hebrew word for "well" (beer). The goal of this modality is to drill down and tap into the mighty, flowing river of creativity, not through expanding the banks of pre-existent channels, but through bringing forth an artesian spring that had remained hidden and untouched. Neither of these thrusts of interpretation may exist independent of the other; they must be brought into attunement.

The encounter with the same religious text or work of music may yield a radical variety of meanings. ${ }^{4}$ The exegete must look for those resonances that are both authentic to the source and uniquely fitting for his or her own time and place. Like a conductor who approaches the score and animates it in a way that it has never before been played, interpretive creativity is the gift of one who stands before the text. The text is brought to life through the melody of its exegesis; therefore, no two peoples' songs will be identical. The text remains the same, just as the musical score remains unchanged, but the attuned vision and educated ear of the interpreter give them new and unique expression.

Sometimes this is a choice on the part of the interpreter, but often there is a deeper force that shapes one's reading. Jewish mystical tradition speaks of a shoresh neshamah, or "soul-root," a particular constellation of character traits and unique intuitive knowledge that governs the encounter with a text. A scholar whose soul is rooted in kindness, for example, will train eyes of benevolence upon the sources of his tradition and share them with others.

3 'Eyn Ayah (Jerusalem: 1995), haqdamah, 14.

4 See Sefat Emet, toledot, 5646. 
Creativity also emerges from quiet moments of sustained listening, from attuning one's mind and heart to a work's liminal spaces. Rabbi Yehudah Aryeh Leib Alter, a Hasidic master known by the title of his masterpiece work Sefat Emet, offers the following remarks on the relationship between exegesis, silence and the melody of freedom:

Some sections of the Torah are uniquely appropriate (meyuhad) for exile, and are therefore closed in (satum). ${ }^{5}$ But others are designated for redemption and freedom. In the Song [of the Sea], there are gaps (parashiyot) in every verse and every line. These reveal the light of Torah.

The sages have taught, "What is the purpose of the spaces? They allow room for contemplation between one section and the next." ${ }^{\prime \prime}$ The redemption of Israel left an impression on the Torah, and the hidden treasure houses of Scripture were opened. This is why it says, "At that time [Moses] will sing" (Ex. 15:1) — the time had come for these illuminations of Torah to be revealed. ${ }^{7}$

Hasidism teaches that exile is primarily to be understood as a state of restricted consciousness or spiritual vision. Redemption, by contrast, comes as one is freed from the shackles of this mindset and comes to see the cosmos - and the text - with a renewed vitality and expansiveness. Often it is through consideration of the white spaces, through creative attention to that which is least obvious about a text that allows the light of meaning to break though. Textual exegesis may become a song of redemption, a melody stitched together from the spaces as well as the text. Such an interpretive song, says the Sefat Emet, may leave an imprint on the text itself, flexing its contours such that it reveals its majesty and mysteries as never before.

This redemptive song of freedom prepared Israel for receiving the Torah at Sinai, opening their hearts and minds to the revelatory moment. ${ }^{8}$ Homiletically linking beer ("well") and bi'ur ("explanation," see Deut. 1:5), the Sefat Emet suggests that another song (Num. 21) readied Israel to begin the ever-expanding project of human interpretation:

The song [of the well] prepared them for entering the land of Israel and the Oral Torah (Torah she-beal peh). This is the meaning of the "mouth of

5 Parashat Va-Yehi begins in the middle of a column in the Torah scroll (see Gen. 47:28). Cf. Bereshit Rabbah 96:1.

6 Bamidbar Rabbah 14:21.

7 Sefat Emet, be-shalah, 5650.

8 Sefat Emet, be-shalah, 5638. 
the well" (pi ha-be'er) [i.e., one of the miracles created in the primordial twilight $]^{9}$-Israel has the power to open up the wellspring of Torah. Of this we say, "He implanted eternal life within us." ${ }^{10}$

The breath of the Eternal, claims Rabbi Alter, has been imbued in the mortal form as an unending wellspring of inspiration. This near-miraculous exegetical font is not divinely given, but actualized through the specifics of human creativity, as the interpreters bring forth new meaning from the sacred reservoir of tradition. We even might say that, in doing so, exegetes mirror the divine by granting eternal life to the texts of the tradition.

Let us dwell for a moment longer with this image of the well as a stream of inspiration. Rabbi Alter often plays upon the difference between "cistern" (bor) and "well" (beer), distinguished from one another by a single Hebrew letter. In one sermon, he explains as follows: "The cistern just contains gathered water; its contents are limited by the size of the vessel that contains them. The well, on the other hand, is joined directly to the source of an ever-flowing spring." ${ }^{11}$ It is from the beer, the well of infinite meaning that is connected to the sources of knowledge, wisdom, and tradition, that we summon forth new interpretations of ancient texts. The cistern, by contrast, represents a mode of thinking inside the box, routinized exegesis undergirded by a tired tradition of threadbare and rehearsed interpretations.

"You, too, have a place to make your own," says Rabbi Kalonymous Kalman Shapira of Warsaw. "In every subject, you can strive forward and delve deeply, revealing a greater part of your power, your vital animating force [nafshekha] and your soul, connecting them to the Torah and to the Infinite One that lies within."12 Exegetical renewal and conceptual innovation, say these thinkers in unison, come through linking ourselves to that ever-flowing interior well at the heart of the tradition, of the text, and the human being.

The inward quest into the depths of this well, the pulsing font of the spirit, is only one part of the quest for meaning. Building on an elliptical phrase from Sefer Yetzirah, ${ }^{13}$ Rabbi Alter claims that "the highest heights

9 See m. Avot 4:6.

10 Sefat Emet, huqqat, 5641-5642. See also ibid., huqqat, 5643, 5645.

11 See the passage translated in Arthur Green, The Language of Truth: The Torah Commentary of the Sefat Emet (Philadelphia: Jewish Publication Society, 1998), 251.

12 Hovat ha-Talmidim (Jerusalem: Undated), ch. 12.

13 See Nehemia Polen, "Birkat Kohanim in the S'fat Emet," Birkat Kohanim, ed. David Birnbuam and Martin S. Cohen (New York: New Paradigm Matrix, 2017), 259-274. 
and the deepest depths depend on one another" ('omek rom ve-'omek tahat teluyim zeh be-zeh). ${ }^{14}$ The deeper one's journeys into a text or a tradition, says Rabbi Alter, the more expansive the scope of the exegesis: "When the innermost root of the Torah is revealed, its illumination may be drawn into every language ... the branches [of a tree] are renewed through the root." ${ }^{15}$ One who sees into the heart of a text will also grasp how it branches into a wide canopy of interrelated ideas. For great scholars, the radiance of Torah spills outward and overcomes might have once been perceived as the boundaries of holiness. Astronomy, history, mathematics, literature, and, of course, music, are infused with sacred vitality through being brought into the concert with the text.

Developing such attuned exegesis is very difficult. It is a long day's work to simply understand the argument of many texts, not to mention subtle ideational resonances, unattributed influences, and conceptual affinities. Unearthing deeper intellectual, philosophical, or religious meaning is not always self-obvious. Texts that we may have seen hundreds of times, such as the book of Leviticus or the Mishnaic order of "Purities" (tahorot), may remain closed books before us. They seem inaccessible, and, for most, utterly irrelevant to contemporary life. Yet, says Rabbi Alter, it is precisely in difficult places that one's efforts will be most rewarding. ${ }^{16}$ The hiddenness of the text is suggestive of its complexity, nuance and richness. The harder and more seemingly arid the textual ground, he claims, the more illumination may be yielded through successful exegesis.

Some literary soil remains particularly hard to penetrate, but it may not be so because of abstruse technical vocabulary. Such mysteries may reflect a lack of willingness in the reader to bring the fullness of his or her self to the encounter with the text:

We know there is something called "hidden wisdom" (hokhmat ha-nistar). I heard from the mouth of the holy Rabbi Menahem Mendel [of Premishlan] that "hidden" refers to something that cannot be communicated to another, like the taste of a food. One cannot speak about it with someone who has never tasted of it. Such things cannot be explained in words. . .

People often call Kabbalah hokhmat ha-nistar, but how is it hidden?! Anyone wishing to study it can surely find the book in front of him! If one

14 Sefat Emet, bereshit, 5636

15 See Sefat Emet, devarim, 5638.

16 See his comments in Sefat Emet, toledot, 5650. 
doesn't understand, it is simply because he is ignorant, and to such a person that Talmud and its commentaries might also be called "hidden"! Rather, the hidden elements of all the Zohar and Lurianic writings are built upon communion (devekut) with the Creator. ${ }^{17}$

One who lacks depth of experience or openness to personal engagement, be it philosophical or spiritual, will miss key aspects of meaning that inhere or may be elicited forth. Such engagement with scholarship is thus, in a sense, a quest for self-discovery, a journey founded in excitement and longing. Rabbi Shapira describes this fundamental yearning for completeness as driving forward the encounter with the text: "The Talmud says that a person will go to great lengths to recover his lost item. One who studies is searching for a part of the self, and delights in the union [when it is recovered]. The student is united [with the lost aspect] of his own essence."18 The study of certain works-musical and textual-must go beyond technique. It requires cultivation of the inner life and the quest for experiential, existential meaning, thus broadening the self and awakening aspects of the subject of one's study.

Rabbi Shapira is one of the select Jewish thinkers who reflected upon the interface between textual creativity and musical innovation. In one teaching, he notes that the faculty of music (described as 'olam ha-niggun) is the patrimony of all, and that one must awaken the soul through retrieving new melodies. ${ }^{19}$ But elsewhere Rabbi Shapira suggests that power may be summoned forth even from careworn melodies. "Song is one of the keys to the soul," he writes, "But we do not need to compose new melodies, just as we do not say that someone who wants to gladden himself with wine needs to do so from his own press, or that one who wants to inspire himself or another else with words needs to invent a new language . . ." ${ }^{20}$ Rabbi Shapira then offers a series of contemplative exercises, techniques intended to allow his readers to study a melody's peregrinations. In order to find deeper-and innovate-meaning, one need not compose a new melody any more than

17 Yosher Divrei Emet (Jerusalem: 1981), no. 22, fol. 122a.

18 Derekh ha-Melekh (Jerusalem: 1995), va-era, 1929, 94, interpreting b. Kiddushin 2b.

19 Tzav ve-Zeruz, printed with Hakhsharat ha-Avrekhim (Jerusalem: Feldheim, 2001), no. $36,389$.

20 Hakhsharat ha-Avrekhim (Jerusalem: Feldheim, 2001), ch. 9:3, 113-114. See Nehemia Polen, "Niggun as Spiritual Practice, with Special Focus on the Writings of Rabbi Kalonymos Shapiro, the Rebbe of Piaseczna," The Contemporary Uses of Hasidism, ed. Shlomo Zuckier (New York: Yeshiva University, forthcoming). 
one might need to invent a new language. Careful attention to a song in the form of aural exegesis allows the seeker to achieve spiritual uplift.

Command of the art interpretation is a journey not achieved in a single day. Like the mastery of chess, or classical music, exegetical skill is refined over many thousands of hours. Yet ultimately, as a quest rather than a question, there can be no total dispositive answers or mastery. Each new vista of achievement must awaken the interpreter to the awareness that just over the next horizon there is another level of meaning, another well to be plumbed. Indeed, quotes Rabbi Levi Yitzhaq of Berditchev in the name of the Maggid of Zlotshev:

One thing I have asked of God, it shall I seek. To gaze upon the pleasantness of God [and to visit His palace] (Ps. 27:4) -I have asked to gaze upon the pleasantness of God, and I will seek it eternally, knowing that there are always higher and higher levels understanding. Even when I attain something, I will continue to seek-this quest is unending. ${ }^{21}$

A text in all of its complexity and depth brooks no mastery. In the continuation of his homily, Rabbi Levi Yitshak offers an image of the Divine as teacher or parent, beckoning us closer only to step back and lead us further yet. Like the pool of meaning at the heart of the text, the divine is perennially hidden yet continuously revealed through our struggle.

We need guides to help us along the path. Such an approach to study cannot be absorbed from a book. Though reading may train our eyes and ears to pick up on subtle resonances in the texts, Hasidism has taught us that we need living teachers to lift a text into the present. This message is the point of an early story, perhaps the earliest such tale committed to print, which describes the first meeting of Rabbi Dov Ber of Mezeritch and his teacher, the Ba'al Shem Tov. After being prompted by the Ba'al Shem Tov to explain a certain passage in a religious text, Rabbi Dov Ber offered a series of learned explanations. The master dismisses each of his interpretations, and then the Ba'al Shem Tov offers his own exegesis of the passage. The house is filled with angelic light, and a ring of fire surrounds the pair of scholars. The Baal Shem tells the Maggid, "Your explanation was correct, but your study was without any soul."22 The duty of spiritual education goes beyond imparting a body of knowledge or interpretation. The teacher is

21 Qedushat Levi ha-Shalem, ed. Michael Darbarmediger (Monsey: 1995), vol. 1, shemot, 143-144.

22 Keter Shem Tov ha-Shalem (Brooklyn: Kehot Publication Society, 2004), no. 424, p. 264. 
tasked with showing the student how to unearth the experiential wisdom hidden in the words of a text. The illuminated educator, like a master conductor, makes the score come to life.

Our remarks thus far have centered upon the power of exegesis and inspired interpretation in relation to sacred texts. But religious communities are not the only smithy in which meaning is forged. Rabbi Professor Nehemia Polen is one of those rare scholars whose religious teachings, spiritual writings, and academic scholarship have come together into a sustained project of interpretive imagination and engagement. Without compromising his intellectual integrity, his work brings forth the sacred from the mundane and expands the reach of Torah. He has shown us a path in which narrow scholarship is directly linked to a quest for ever-broadening depth and connectivity. Often he does not make the point explicitly, but a reader of his work who is attuned to the inner music of the interpretive process discussed above will feel clear echoes of it in both the tone and content of Polen's writings. Those who have had the privilege of being his students will also know the energy and absorption in the sources reflected in his enthusiastic teaching style, ever seeking to penetrate the written sources to allow the student to glance at the inner experience that lies behind and within them.

The breadth of his scholarship reflects the many turns and developments in Professor Polen's own life. Raised in a traditional and learned family and given a yeshivah education at Ner Israel, where he studied with the great Rabbi Ruderman, Polen achieved a degree in mathematics from Johns Hopkins University. He left Baltimore in the quest for a more expansive approach to Jewish learning, joining the intentional community of Havurat Shalom, founded by his friend, and now colleague, Arthur Green, one of the editors of the present work. After the sudden death of his father Rabbi David S. Polen, he answered the call to become rabbi of his father's synagogue in Everett, Massachusetts. There he served with his mother Nettie Polen, who continued in her role as senior rebbetsin, and he remained at this post for twenty-three years. After his first year in Everett, Polen married Lauri Wolff, whose joyful presence illuminated the community as well as their growing family.

During his tenure as rabbi, Polen began his doctoral studies at Boston University. His dissertation and subsequent book on Rabbi Kalonymous Kalman Shapira, written under the guidance of Elie Wiesel, launched an entire sub-field of study, which Polen has complemented with a wide variety 
of works on early rabbinic, biblical theology, and Hasidic thought. Polen became one of the core faculty members of the Boston Hebrew College, joining the faculty of its post-denominational rabbinical school.

The central pillar in Polen's life across these many decades has been, and remains, his wife and life's companion Lauri. The loving partnership at the heart of their shared intellectual and spiritual journey is founded in mutual encouragement, admiration and inspiration. In every element of Polen's writing and teaching there is an unmistakable glow that resonates with Lauri's wisdom, unflagging support, and generosity of spirit.

It is our honor to present this volume to Professor Polen, a scholar and educator whose illuminated exegesis has inspired so many over the course of many decades. Many of his students have become teachers in their own right, and countless others have gone on to live much richer and deeper lives in dialogue with the texts at the heart of our intellectual and spiritual tradition. The essays in this collection, from his students, colleagues, and friends, are a testament to his enduring impact on the scholarly community. The contributions explore with a range of historical periods and themes, centering upon the fields dear to Polen's heart, but a common thread unites them. Each essay is grounded in deeply engaged textual scholarship that casts a glance upon the sources that is at once critical and beneficent. In cultivating this approach, Professor Polen, we are all your students.

"What we need more than anything else is not textbooks but text people," Rabbi Abraham Joshua Heschel said in an essay on contemporary Jewish education. "It is the personality of the teacher which is the text that the pupils read; the text that they will never forget." ${ }^{23}$ In his remarks about the craft of Hasidic exegesis, Professor Polen has offered the following remarks:

The interpretive dynamics of early Hasidism depend crucially on the personhood of the interpreter engaging with the personality of Torah, effectively identical with the personality of God. The Hasidic interpreter not only applies a method, but also explores and reveals the personal aspect of self and of Torah, in dialogue with each other. To be sure, the mystical teachings-omnipresence of God, illusory nature of evil, the creation of the world anew every moment-frame and influence the teachings, but it

23 Abraham Joshua Heschel, "Jewish Education," The Insecurity of Freedom: Essays on Human Existence (New York: Schocken Books, 1972), 237. 
is also true that the masters celebrate the individuality of interpretation as reflecting the stamp of each unique personality. ${ }^{24}$

An old Hasidic adage has it that the pious who rejoice with the Law on the festival of Simhat Torah are its feet. The same may be said of the exegetes who bring the Torah to life. Such interpretation is not about overcoming the plain-sense of a text or foisting an idea onto it. Hasidic masters, argues Polen, listen deeply to the nuances of the text and, through their living exegesis, allow it to begin to speak.

Na'eh darash, na'eh kiyyem. Professor Polen is a text person of whom Heschel would be proud, a teacher whose scholarship and Torah continue to inspire his students and colleagues. The Ba'al Shem Tov recommended that one find a teacher whose Torah never stops growing. Limited masters, he said, offer only constrained fragments of the Torah-like the Rabbi Alter's cistern, it is a brackish Torah. The words of a great teacher, claims the Ba'al Shem Tov, embody the injunction to "be fruitful and multiply." They grow and mature across the years, blossoming in new and distinct forms as they take new root in each new student. Dear Nehemia, we bless you: May your writing and teaching continue for many long years, and may your splendid works continue to be fruitful and multiply. This wish is offered by your community of scholars, friends, students, and family, and the contributors to this volume, representing but a small number of those who have been touched by this remarkable scholar.

Ariel Evan Mayse and Arthur Green

Berkeley and Boston Erev Rosh Ha-Shanah

24 Nehemia Polen, "Hasidic Derashah as Illuminated Exegesis," The Value of the Particular: Lessons From Judaism and the Modern Jewish Experience, Festschrift for Steven T. Katz, ed. Michael Zank and Ingrid Anderson (Leiden and Boston: Brill, 2015), 55-70. 
